\title{
Challenges of Sustainable Tourism Development in Jimma, Buno Bedele and Nekemt Town, Oromia Region, Ethiopia
}

\author{
Shimekit KELKAY ${ }^{1 a}$,Yeshiwas ABUNIE ${ }^{b}$, Sukarn SHARMA ${ }^{a}$ \\ a Department of Hospitality and Tourism Management, Jimma University, Ethiopia \\ ${ }^{b}$ Department of Tourism Management, University of Gonder, Ethiopia
}

\begin{abstract}
The south west Oromia Region of Ethiopia is having great potential for cultural and natural heritages in the Jimma, BunoBedele and Nekemt towns. In this region, there is a requirement to rebuild the economy, while preserving and conserving the socio-cultural and the natural environment for future. One of the ways to do so can be the development of sustainable tourism. Therefore, to gather in-depth information about the challenges of sustainable tourism development at the above stated towns, face-to-face interviews, observation and surveys were carried out. The study was conducted in November, 2018 and the respondents that participated in the study were 150. According to the findings, the main challenges of sustainable tourism development in the study area are an expansion of agriculture in the protected areas, the frequent incidence of wild fire, lack of facilities at the concerned area, low level of knowledge of the locals to showcase and protect their cultural heritage as well as weak legal systems. The level of participation of local people in tourism development was also low at the time of the study, but they showed interest in gaining education and training regarding sustainable tourism and wanted to participate in the decision making process.
\end{abstract}

Key words: Sustainable tourism, tourism challenges, development, environment, local community

\section{Introduction}

In reviewing the desired goal of tourism in rural areas McAreavy and McDonagh (2011) argues that tourism needs to be viable, but it should not harm the resources such as physical environment and social fabric of the host community i.e. tourism development should be sustainable. Tourism is a development indicator. Indeed, it is an index of mobility and a factor of socialization. It calls and creates an opportunity to transfer income from the more privileged to the less privileged, access to knowledge,

\footnotetext{
${ }^{1}$ Corresponding author: Shimekit KELKAY, e-mail: skelkay@gmail.com. Received in August, reviewed in September, Published in October 2019.
} 
expansion of partnerships, enhances diversified involvement and participation and cross-fertilization of cultures. It is also an indicator of levels of cross boundary achievements (Kamamba, 2003). Tourism has increased due to more leisure time, more income and high mobility, a result of increased car ownership, national and international road/sea/air public transportation systems and information technology. Tourism is arguably the largest industry in the world, generating close to million dollars, which is $12 \%$ of the world total (UNESCO, 2003).

The integrated approaches to tourism planning are neither top-down nor bottomup. They may rather be regarded as an interactive or collaborative approach, which requires participation and interaction. Getz and Jamal (1994: 152) suggest that "in a complex tourism domain, no single individual, agency or group can resolve strategic tourism issues by acting alone".

According to the World Bank (1996), stakeholders' participation throughout the tourism sector in Ethiopia is weak and shallow offering little opportunity for benefits from tourism to disperse to the local community. Aside from the employment generated in the formal sectors (hotels, transport, tour operators) there are few opportunities for poorer Ethiopians to be involved in tourism in terms of decision making and benefit sharing (Ashley, 2006). The towns of Jimma, Buno Bedele and Nekemt, are areas of friendly people who have a good tradition of keeping their environment political system and are worth visiting. The culture, history, the tradition of the people and their resources are well kept in Jimma and Nekemt museums as well as at king Aba Jifar's Palace in Jimma. These areas also have a rich collection of cultural, historic and natural attractions that put it at a favourable position to develop the tourism industry. The historic palace of Abba Jiffar, the Museum of Jimma, the palace of Dejazmach Kumsa Moroda, rivers, waterfalls, gorges, dense tropical natural forests like Yayo forest with its different species of wildlife, coffee plantations, mountains and plains offers numerous attractions to the tourists. However, even after having so many attractions the area has neither been able to realize its true tourism potential nor been able to generate economic benefits. There is very low support and little or no delegation of tasks to nongovernmental organizations as well as no public private partnership initiatives in the field of tourism development. Joined with neglect, poor cooperation, and inadequate financial support the very survival of Jimma, Buno Bedele and Nekemt towns' tourism development is in jeopardy. So this research basically examines the challenges faced in the development of tourism in the concerned areas in a sustainable manner. 


\section{Review of Literature}

Over the last two decades, the concept of sustainable tourism development has become almost universally accepted as a desirable and politically appropriate approach to tourism development (Sharpley, 2003). However, the highly complex and fragmented structure of the tourism sector remains a key challenge in achieving consensus and developing coherent sustainable tourism strategies (Papatheodorou, 2004).

Due largely because what is sustainable varies from one situation to another, it is generally accepted that no absolutely true nature of sustainability can be found (Mowforth \& Munt, 1998). What is perhaps more significant though, is that the goal of sustainable development may be providing an "impetus for structural change within society" (Fennell, 1999:13). The main goal of the tourism association should be to develop an integrated, continuous passage for sustainable tourism mobility, which improves the possibilities for smooth, problem-free and environmentally friendly travel (Verbeek, Bargeman, \& Mommaas, 2011).

Sustainable tourism has maintained a prominent position in tourism policy and planning process and in academic study since the early 1990's due to both negative impacts of tourism and alternative approaches to the development of tourism (Yazdi, 2012). It has been adopted by both the public and private sector at all levels of governance and in organizations such as United Nations Environment program (UNEP), United Nations World Tourism Organization (UNWTO), and the World Travel and Tourism Council (WTTC) (Hall, 2011).

The early approaches to sustainable tourism thinking were quickly criticised for being too simple and too impractical as they overlooked tourism's complex and dynamic nature, as well as offered no practical solutions to the rapid growth of tourist numbers. It is also recognized that these views took what may be considered as being a 'tourist-centric' approach and may well have co-evolved with earlier definitions of sustainable tourism. Later definitions move away from the initial failure to recognise the importance of other industry sectors and the broader perspective of sustainable development (Hunter, 1995) which resulted in the motivation to change mass tourism to more sustainable forms (Butler, 1991). This led to a situation, which differed from previous views in three important ways (Clarke, 1997):

- The issue of tourism's scale became more objective and less emotive. Mass tourism became the subject for improvement, rather than the derided villain.

- Sustainable tourism became the goal for attainment, rather than the possession of existing scale of tourism. 
- Operational current knowledge to move towards the goal became the practical focus of effort.

In viewing tourism this way, the links to sustainable development were reinforced to some extent and this resulted in the demand to change mass tourism to more sustainable forms. Most recent understandings of sustainable tourism are then being as a goal that all tourism must aim for. In this view, "the absence of a precise definition of sustainable tourism is less important than the journey towards it" (Hardy \& Beeton, 2001:172). Within this approach, the wider role of sustainable development is most fully appreciated. The large-scale interpretation is now seen to have a dominant physical/ecological perspective expressed as a business orientation, and the small-scale version offers a social dimension from a local or destination platform. On the convergence of these two forms, both interpretations:

- Focus on the implementation of their current knowledge of sustainable tourism to move towards the ultimate goal of sustainability;

- Seek future progress towards the desired goal through the twin processes of further development of ideas inherent in their own interpretation and by adaptation of ideas found in the other.

Taking arguments to the extreme, some maintain that all tourism has negative impacts on the natural world and its populations, and therefore from this position it would be impossible to conceive of tourism as ever being sustainable (Sharpley, 2000). At the other extreme, humans are viewed as living organisms whose behaviour is natural and who have no obligation or responsibilities to consider other living things. Therefore, people are unable to behave unnaturally and so all tourism is 'sustainable' in the sense of satisfying the desires of some people. In reality all of the proposed definitions can be considered as lying somewhere in between these positions (Garrod \& Fyall 1998).

Bramwell and Lane (1993) have identified four basic elements that are critical to the concept of sustainability: holistic planning and strategy formulation; preservation of essential ecological processes; protection of both human heritage and biodiversity; and development in which productivity can be sustained over the long term for future generations. These basic elements have been adapted to develop seven principles, or criteria, which have been used to assess sustainable development (Bali Sustainable Development Project, cited in Wall, 1993).

The principles developed are: ecological integrity, efficiency, equity, cultural integrity, community, integration-balance-harmony, and development as realisation of potential. It is recognised that at least three of these are particularly appropriate to a discussion about stakeholder participation (Timothy, 1999). Efficiency is concerned 
with making the best use of resources (especially time, money and personnel). Equity refers to equality of opportunity and recognition of needs amongst various stakeholders. Integration-balance-harmony refers to the struggle between key factors, such as environment and economy, sectors such as agriculture and tourism, and in patterns of regional development (Wall, 1993:55). The challenges facing the tourism industry are complex and numerous. Changing demographics, shifting travel patterns and volatile economic conditions are increasing the pressure on industry stakeholders to develop effective campaigns and business strategies.

Community participation is often suggested as an essential ingredient in improving the quality of tourism's contribution to national development. Moreover, local involvement is believed to be able to create larger and balanced economic opportunities, especially for the poor, increase local tolerance and positive attitudes to tourism development, and facilitate the implementation of the principles of sustainable tourism. However, lack of tourism knowledge is critical barrier that limits the ability of locals to participate in tourism development which contributes to a lack of local tourism leadership and domination of external agents (Gebeyaw, 2011). Moreover, there is a lack of a proper marketing strategy in destinations of developing countries to promote tourism development and also they are unable to compete with intruders from outside markets (Cusack \& Dixon, 2006).

The challenge of implementing sustainable tourism is that tourism is a complex adaptive system with many independent actors (Farrell B, Twining-Ward L 2005). Delivery of tourism experiences requires many companies working in concert to provide product and services to travelers. The system is dynamic and self-organizing. Tourism does not have a "top down" structure. The recognition of this insight has required policy makers to reexamine their approaches to the role Destination Marketing Organizations (DMOs) in the implementation of sustainable tourism programs. Appreciation of the complexity of governance issues in sustainable tourism policy implementation has grown significantly since Agenda 21 for the Travel and Tourism industry report noted "National Tourism Authorities (NTA) have been responsible for marketing, planning and advising central governments on travel and tourism issues (UNWTO, 1997).

Informed participation of all relevant stakeholders, as well as strong political leadership is essential for sustainable tourism development so as to have wide participation and consensus among the population. It needs to be understood that sustainable tourism is a continuous process and would require introduction of the necessary preventive and/or corrective measures whenever necessary as well as constant monitoring of impacts. A meaningful experience along with high level of 
tourist satisfaction, good levels of awareness about sustainability issues and promotion of sustainable tourism practices are important factors of sustainable tourism (Niedziółka1, 2010).

There is now increasing agreement on the need to promote sustainable tourism development to minimize its environmental impact and to maximize socio-economic benefits at tourist destinations. The concept of sustainable tourism, as developed by the WTO in the context of the United Nations sustainable development process, refers to tourist activities "leading to management of all resources in such a way that economic, social and aesthetic needs can be fulfilled while maintaining cultural integrity, essential ecological processes and biological diversity and life support systems" (UN, 2001a).

\section{Materials and Methods}

The study had employed a cross-sectional descriptive research method. The target population for this study were Jimma, BunoBedele and Nekemt town administrative, cultural and tourism office, Ethiopian wildlife conservation authority, staff of media, tour guides, religious institution leaders, local community representatives from government sectors, hotel and lodge managers, higher institution professionals, nongovernmental organizations who are working together with cultural and tourism office of Jimma, BunoBedele and Nekemt town and those volunteer organizations who are purposefully involved in cultural and natural heritage conservation process in the area.

According to (2016) Jimma, BunoBedele and Nekemt Cultural and tourism administrative office the towns have a total population of 250 that have a direct relationship with tourism concepts. Therefore, the sample size that the researcher used was about 154 for the study of the total target population of 250, based on Yamane's formula:

$$
\mathrm{n}=\mathrm{N} / 1+\mathrm{N}(\mathrm{e})^{2}
$$

Where $\mathrm{n}$ is for required sample size, $\mathrm{N}$ is total population and e is margin of error (.05) (Yamene, 1967).

A pilot survey was also conducted on 10 random respondents out of the sample size in order to test reliability of each item of the instrument. Primary data for the study was collected from participants by administering close ended questionnaires which measure the items on a five point Likert scale. The attributes for the study were based upon the researches regarding sustainable tourism development in the last five years and upon the opinions of officers of the tourism department and managers and experts from the industry. The completion of the questionnaires was 
entirely based on a voluntary basis. A cover page was attached to the questionnaire explaining the objective and importance of the research so as to inspire the respondents to fill the questionnaire properly and provide genuine response. Data collected were analyzed by using Statistical Package for Social Sciences 19.0. Out of the 154 questionnaires 4 were not fully filled and therefore, only 150 were used for the study.

\section{Results and discussion}

In order to assess the challenges about sustainable tourism development, respondents were asked-to rate their level of agreement or disagreement with a series of statements, on four factors, i.e. natural \& man-made, cultural tourism resource, attitudes \& perceptions and other challenges using a five point Likert scale, (Table 1).

The higher the mean score, the stronger the agreement is, the results on the table above reveal that there was strongest agreement among the factors in natural resources towards "expansion of agricultural practices towards protected areas" (Mean= 4.53 SD = 0.67) and "frequent incidence of wild fire" (Mean = 4.2, SD=0.59). Even the other factors such as "grazing at heritage sites", "deforestation of natural areas" and "frequent drought and flood" have also been agreed by most of the respondents (mean rating of more than 3.9) as detrimental and posing a huge challenge for development of sustainable tourism.

It seems from above that the local population is not having enough income opportunities and the towns are also facing issues posed by natural as well as manmade disasters. It has to be understood that tourism cannot be developed in isolation without giving due regard to the livelihoods of the local population. The locals must have vested interests in the development of tourism. However to engage them actively in tourism projects, proper training and education can be given. This will provide the local population with regular income from tourism and they themselves will also feel responsible to protect the environment on which tourism is built upon. One should consider human-wildlife conflicts while developing tourism plans and should try to minimize them. The ideal way of developing tourism sites should be done in such a manner that it does not harm the environment, but the money earned through it should help preserve the environment.

Whereas cultural resources are concerned the respondents stated that "lack of museums and archival centres" (Mean $=4.52, \mathrm{SD}=0.72$ ), "poor conservation practices" (Mean $=4.25, \mathrm{SD}=0.62$ ), "lack of emphasis to the intangible aspects of heritages" (Mean $=4.24, \mathrm{SD}=0.62$ ), "theft/looting of resources related to tourism" 
(Mean $=4.19, \mathrm{SD}=0.72$ ) are the main challenges. Though "modification of the cultural tourism product" so as to appeal to the tourists (loss of authenticity), "poor handling system of resources", "conflict of interest over resource ownership" and "illicit trafficking" were also identified as additional challenges (Table 1).

Table 1.Challenges of sustainable tourism development

\begin{tabular}{|c|c|c|c|c|c|}
\hline \multicolumn{6}{|c|}{ Natural Tourism Resource } \\
\hline & $\mathrm{N}$ & Min. & Max. & Mean & Std. Dev. \\
\hline Frequent occurrence of drought and flood & 150 & 1.00 & 5.00 & 3.9267 & .60309 \\
\hline Conflict of interest over resource ownership & 150 & 1.00 & 4.00 & 3.2600 & .57264 \\
\hline Frequent incidence of wild Fire & 150 & 2.00 & 5.00 & 4.2333 & .59547 \\
\hline Deforestation activities of natural areas & 150 & 1.00 & 5.00 & 3.9400 & .43704 \\
\hline Grazing at heritage sites (mainly protected areas) & 150 & 2.00 & 5.00 & 3.9600 & .32523 \\
\hline $\begin{array}{l}\text { Expansion of agricultural practices towards } \\
\text { protected areas }\end{array}$ & 150 & 2.00 & 5.00 & 4.5333 & .67224 \\
\hline Expansion of illegal settlement & 150 & 1.00 & 5.00 & 3.0267 & 1.4187 \\
\hline \multicolumn{6}{|c|}{ Cultural Tourism Resource } \\
\hline Illicit trafficking & 150 & 1.00 & 5.00 & 3.9200 & .51187 \\
\hline Poor handling system of resources. & 150 & 1.00 & 5.00 & 3.9400 & .37056 \\
\hline Theft/looting of resources related to tourism & 150 & 1.00 & 5.00 & 4.1933 & .72996 \\
\hline $\begin{array}{l}\text { Modification of cultural tourism product so as to } \\
\text { appeal to the tourists (Loss of authenticity) }\end{array}$ & 150 & 1.00 & 5.00 & 4.1533 & 1.1217 \\
\hline Conflict of interest over resource ownership & 150 & 1.00 & 4.00 & 3.9267 & .32967 \\
\hline Poor conservation practices & 150 & 1.00 & 5.00 & 4.2533 & .62591 \\
\hline Lack of museums and archival centres & 150 & 1.00 & 5.00 & 4.5267 & .72996 \\
\hline $\begin{array}{l}\text { Lack of emphasis to intangible aspects of } \\
\text { heritages }\end{array}$ & 150 & 1.00 & 5.00 & 4.2467 & .62323 \\
\hline \multicolumn{6}{|c|}{ Attitude and Perceptions } \\
\hline $\begin{array}{l}\text { I am happy with the existence of tourists in my } \\
\text { area }\end{array}$ & 150 & 1.00 & 4.00 & 3.6200 & .53933 \\
\hline $\begin{array}{l}\text { I believe that tourism creates market opportunity } \\
\text { for local product }\end{array}$ & 150 & 1.00 & 4.00 & 3.2800 & .53244 \\
\hline $\begin{array}{l}\text { Stakeholders' participation in the development of } \\
\text { tourism is imperative }\end{array}$ & 150 & 1.00 & 4.00 & 3.5867 & .60409 \\
\hline $\begin{array}{l}\text { I am willing to participate in sustainable tourism } \\
\text { development }\end{array}$ & 150 & 1.00 & 5.00 & 4.2267 & .65689 \\
\hline $\begin{array}{l}\text { I am willing to take tourism education and } \\
\text { training }\end{array}$ & 150 & 2.00 & 5.00 & 4.2400 & .59843 \\
\hline $\begin{array}{l}\text { I have the sense of ownership to tourism } \\
\text { resources }\end{array}$ & 150 & 1.00 & 4.00 & 3.5600 & .66028 \\
\hline \multicolumn{6}{|l|}{$\begin{array}{ll} & \text { Other Challenges }\end{array}$} \\
\hline Lack of awareness is a challenge to tourism & 150 & 1.00 & 5.00 & 3.9400 & .88409 \\
\hline Lack of appropriate legal system & 150 & 1.00 & 5.00 & 4.4600 & .92417 \\
\hline
\end{tabular}

Source: (Own data 2018) 
It can be stated that due to underfunded tourism projects there is a lack of facilities to showcase the culture. Tourism is a highly competitive industry and therefore, to attract the tourists and elongate their stay, appropriate infrastructure has to be built (Table 1 ).

However at the same time it should be ensured that development is not taking place at the cost of the environment i.e. all development should be sustainable. In addition, the local population is not appropriately apprised about the culture and trained regarding conservation and promotion practices. The legal system also appears to be weak and commercialisation of culture (where possible) to such an extent that the authenticity is being compromised are the main issues. Towns are not able to develop to their fullest possible potential because of this and therefore, are unable to reap the benefits of tourism. An active and beneficial involvement of the local population in the development of tourism after proper training and development of an effective legal system that can help protect the cultural heritage cannot be underestimated.

It is quite nice to see that attitude and perceptions of stakeholders towards sustainable tourism development are quite positive. The respondents showed the strongest support for the idea that "I am willing to take tourism education and training" (Mean $=4.24, \mathrm{SD}=0.59$ ) and "I am willing to participate in sustainable tourism development" (Mean $=4.22, \mathrm{SD}=0.65$ ). Though it is surprising that at the same time the attribute "I am happy with the existence of tourists in my area" (Mean $3.62 \mathrm{SD}=0.53$ ), "stakeholders' participation in the development of tourism is imperative" (Mean $=3.58, \mathrm{SD}=0.6$ ), "I have the sense of ownership to tourism resources" (Mean $=3.56, \mathrm{SD}=0.66$ ) and "I believe that tourism creates market opportunities for local product" (Mean $=3.28 \mathrm{SD}=0.53$ ) have not received very high mean ratings.

It appears that the local population is interested in learning and applying the principles of sustainable tourism, but at the moment they are having a very low level of awareness about the requirements and of the ways to make their livelihood from tourism. Many of them are not sure that the presence of tourists is essential for the development of tourism and how the involvement of all the stakeholders will help develop sustainable tourism. Further, due to lack of involvement in tourism as well as awareness they don't feel themselves connected to the resources and also don't know whether the tourists even after coming would buy their products. With short term trainings, the locals can understand the requirements for developing tourism and that too in a sustainable manner. Apart from this, after developing skills through training local population can have active engagement in tourism activities which will make 
them feel a part of the system. The development of practices of cooperative marketing for local products with the initial assistance from the government can also be helpful.

In consideration of other challenges faced in the development of sustainable tourism respondents felt that "lack of appropriate legal system" (Mean $=4.46, \mathrm{SD}$ $=0.88$ ) is an issue. Even "lack of awareness" (Mean $=3.94, \mathrm{SD}=0.92$ ) is also there regarding the benefits of sustainable tourism.

As has been pointed above education and enforcing laws to protect the natural as well as cultural environment is vital to harness the benefits of tourism. In addition the local population will automatically become the preserver and protector of their culture and natural environment if they have a sense of pride regarding it.

\section{Conclusions}

The respondents identified a number of challenges of sustainable tourism development in the area of Jimma, Buno Bedele and Nekemt towns. It was revealed that expansion of agricultural practices towards protected areas and frequent incidence of wildfire is one of the biggest issues amongst sustainable development of natural tourism resources. Similarly, in the case of cultural tourism resources the lack of museums and archival centres, poor conservation practices, lack of emphasis to the intangible aspects of heritages, theft/looting of resources related to tourism are the main challenges. The attitude and perceptions of stakeholders are quite favourable towards sustainable tourism development and they have also shown interest in tourism education and training. However the respondents did not have the awareness of the ways in which they can participate to harness the benefits out of tourism in a sustainable manner. Therefore, active involvement of the local population in the decision making process regarding tourism policies in their area so as to minimize interest conflicts and to have their gainful participation in tourism projects is of utmost importance. In this regard facilitating the locals along with providing them training through the local universities and enacting a strong legal framework is the way forward. This will help to take care of the income of the people, provide a delightful experience to the tourists and will also ensure preservation of the natural and cultural environment. In the future similar researches regarding tourism sustainability may be conducted at other tourism destinations of Ethiopia as well. 


\section{References}

1. Ashley, C. 2006. How Can Governments Boost the Local Economic Impacts of Tourism? Overseas Development Institute, SNV.

2. Bramwell, B. \& Lane, B., 1993. Sustaining tourism: An evolving global approach. Journal of Sustainable Tourism, Vol. 1(1), 1-5

3. Butler, R., 1991.Tourism, Environment \& Sustainable Development, Environmental Conservation, Vol. 8(3), p. 201-9.

4. Clarke, J., 1997. A framework of approaches to sustainable tourism, Journal of Sustainable Tourism, Vol. 5, p.224-233.

5. Cusack, D., \& Dixon, L., 2006. Community-Based Ecotourism and Sustainability, Journal of Sustainable Forestry, Vol. 22(1-2), p.157-182: http://dx.doi.org/10.1300/J091v22n01_09.

6. Farrell, B, Twining-Ward ,L., 2005. Seven Steps Towards Sustainability:Tourism in the Context of New Knowledge. Journal of Sustainable Tourism, Vol. 13: 109-122.

7. Fennell, D., 1999. Ecotourism: An Introduction. London: Roudedge.

8. Garrod, B., \& Fyall, A., 1998. Beyond the rhetoric of sustainable tourism? Tourism Managements, Vol.19(3), p.199-212.

9. Gebayaw, Ambelu, 2011.Practices, Challenges and Opportunities of Community Based Ecotourism Development In MeketWoreda, North Wollo Zone, Amhara Region, Unpublished Thesis.

10.Getz, D., \& Jamal, T.B., 1994. The environment-community symbiosis: A case for collaborative tourism planning. Journal of Sustainable Tourism, Vol. 2 (3), p.131-136.

11. Hall, C. M.,2011. Policy learning and policy failure in sustainable tourism governance: From first- and second-order to third-order change? Journal of Sustainable Tourism, Vol.19, 649671.

12.Hardy, A.L., \& Beeton, R.J.S., 2001. Sustainable Tourism or Maintainable Tourism: Managing Resources for More Than Average Outcomes, Journal of Sustainable Tourism, Vol. 9 (3), p.168-192.

13. Hunter, C.J., 1995. On the need to re-conceptualise sustainable tourism development, Journal of Sustainable Tourism, Vol. 3 (3), p.155-65.

14. Kamamba, D.M.K., 2003. Conservation of Dares Salaam City (Unpublished MA thesis, 2003).

15. McAreavy, R., McDonough, J., 2011. Sustainable Rural Tourism: Lessons for Rural Development, in McDonagh, J., Varley, T. and Shortall, S. A Living Countryside - The Politics of Sustainable Development in Rural Ireland, Ashgate Aldershot, p.219-234.

16. Mowforth, M. \& Munt, I., 1998.Tourism and sustainability: new tourism in the Third World. Roudedge: New York.

17. Niedziółka1, I., 2010. Sustainable Tourism Development. Regional Formation and development Studies, 159.

18. Papatheodorou, A., 2004. Exploring the evolution of tourism resorts. Annals of Tourism Research, Vol. 31, 219-237.

19.Sharpley R., 2000. Tourism and Sustainable Development: Exploring the Theoretical Divide, Journal of Sustainable Tourism, Vol. 8(1), p. 1-19.

20.Sharpley, R., 2003. Rural tourism and sustainability - A Critique. In D. Hall, L. Roberts, \&M. Mitchell (Eds.), New directions in rural tourism (p. 38-53). Aldershot: AshgatePublishing Limited.

21.Timothy, D., 1999.Participatory planning. A view of tourism in Indonesia, Annals of Tourism Research, Vol. 26 (2), p.371-391.

22. United Nations, 2001a. Sustainable development of tourism, Report of the Secretary-General. E/CN.17/2001/PC/21. United Nations, New York.

23.UNESCO, 2003. Convention on Intangible Heritage: Practical Implications for Heritage Management Approaches in Africa. 
24.UNWTO, 1997. Agenda 21 for the Travel and Tourism Industry: Towards Environmentally Sustainable Development. World Travel and Tourism Council; $\quad$ United Nations World Tourism Organization; The Earth Council.

25.Verbeek, D. H. P., Bargeman, A., \& Mommaas, J. T., 2011. A sustainable tourism mobility passage. Tourism Review, Vol. 66, 45-53.

26.Wall, G., 1993. International collaboration in the search for sustainable tourism in Bali. Journal of Sustainable Tourism, Vol. 1(1), p.38-47.

27.Wall, G., 1993.Towards a tourism typology, in Monitoring, Planning, Managing, eds. J.G. Nelson, R.W. Butler and G. Wall, p. 45-58. Waterloo, Ontario: University of Waterloo (Department of Geography Publication 37).

28.World Bank, 1996. The World Bank participation sourcebook, http://www.worldbank.org/wbi/sourcebook/sbhome.htm (accessed on March18, 2018).

29.Yamane, T., 1967. Statistics: An Introductory Analysis, 2nd Edition, New York: Harper and Row.

30.Yazdi, S. K., 2012. Sustainable Tourism. American International Journal of Social Science, Vol. 1(1), p. 51-56

(C) 2019 by the authors. Submitted for possible open access publication under the terms and conditions of the Creative Commons Attribution-Non Commercial-No Derivatives (CC BY NC ND) 4.0 International License. (https://creativecommons.org/licenses/by-nc-nd/4.0/). 